Bugünki adli faaliyet sadece şu iki soruya cevap aramaktadır. Maznun suçu işlemiş midir? Işlemiş ise hâdiseye en iyi uyan kanun maddesi hangisidir? Birinci soru hâkime suç denilen fuilin zan altında bulunan kimse tarafından işlenmiş olup olmadığını araştırmak ödevini tahmil eder. $\mathrm{Bu}$ şüphesiz halli gereken bir meseledir. Fakat adaleti temin için suçun maznun tarafından işlendiğinin ispatı kâfi gelmez. Acaba fïlin, fäle atfedilmesi mümkün müdür? Suçlunun iradesi üzerine müessir, sayısız ruhi ve içtimai hâdiseler mevcuttur. $O$ halde/ (sụ̧ sabit olmuştur) sözü ile iktifa etmek kâfi değildir. Bu safhadan iler: gitmeyen, ilerisini araştırmayan hâkim vazifesini yapmı̧ sayılmaz.

Ikinci soruya gelince, hâdiseye tatbik edilecek en iyi kanun maddesini bulmak işi surf bir şekil faaliyetidir. Suçlu insan tipi ve onun psikolojisi $\left.{ }^{2}\right]$ büyük bir tenevvü arzeder. Zaten birbitine psikolojik bakımdan benzemelerine imkân olmıyan insanların bir de anormal unsurlarla derece derece, muhtelif dozlarla bozulmuş olduklarr düşünülï̈rse vüicuda

[1] Bibliograti: RIBOT (Th.) L’hénédité psydbologique, Paris, 1925. - GELLY (Gustave) l'être suboonscient, Paris, 1926. - CHRETIEN (Henri) Le toucher, Paris, 1925.LEBON (Gustave) Psycologie des foules, 38 inci basilıs, Paris, 1931. - NAST (Mancel) Le vagabondage et la prostixutiolu des mineurs, Panis, 1909. - PRUDON (Rorger) 1'alcoodisme et ses toxicomanies au point de vue penal, Paris, 1936. - ZERBOGLlO (Adolfeo) Cocasidetazioni circa lo studio della personalita del delincunente Criminalia, 1938, Dicenkisre, fasc. III-IV, s. 132. - THOMAS (Maurice) l'tintinot, Panis 1929. - GARAFALO (R.) La crimonologie, Paris, 1905. - FERRI (Enrico) La soologie criminelle, Paris, 2 aci basjlis,

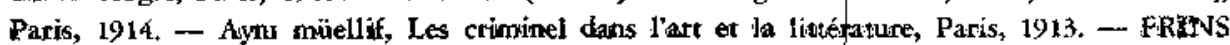
(A.) Science pśnale en ide droit posàtif, Bruxelles, 1899. - KESLER, susyoloji. - GÖKAY (Fahrettin Kerim) Ruh hasealiklarn, 5 kinci basslıs, Ist. 939. - NEVILLE (Andué) Vernsetin sitolojilk esaslar, ünivensite konferansları, 935-936, s. 203. - COOPER-C,OLE (Fay), şeviren, Mediha Berkes, Medeniyete giden uzun yol, Ankara 1943. - DURU (Kazman Nami) Sosyobojinin unsurlar, Ist. 1936. - Enem, Ceza evlerinde cezanno ferdilestirilmesi, Ad: Ceridesi, 940 s. $7721-781$. 
gelen halitenin yani SUÇLU - INNSAN'ın kanun vazı tarafından, onı tanımadan tesbit ettiği kategorilerden hiçbirine sıgmayacağı anlaşılır [ ["] Hâkimin büyük emek sarfederek bulduğu (hâdiseye en iyi uyan kanun maddesi) ortalama bix hesap, basit bir tahminden ibaret kalır. Bu sebeple münhasıran işlenilen suça bakarak suçluya ceza vermek cezanın ferdileştirilmesi kaidesinin tatbikını mümkün kılmaz. Çünkü işlenilen suçun nevi ile suçlunun şahsiyeti arasında kati bir münasebet yoktur. Eğer suç luyu uslâh edecek bir Tedbir - Ceza'nun tesbiti icabediyorsa her şeyden evvel maddi bir hâdise olan ve işlenmesi ile artık maziye karışmış diyebileceğimiz suçu değil, yaşayan ve yaşamasında belkide cemiyet için faide beklenilebilecek şahıs iizerinde durmak lâzım gelir. Suç işlenmiş olsa dahi, cemiyetin bir ferdini cemiyet dişı etmeğe, mücbir sebepler olmadıkça. hâkimin hakkı yoktur.

Hülâsa edecek olứsak bugün münhasıran suç ile meşgul olunmak: ta, suçlu ihmal edilmekte veya pek az nazara alınmaktadır, diyebiliriz. Bütün suçlular aynt seviyede kabul ediliyor, mutavasstt bir suçlu tipi örnek alınyyor. Şüphesiz anormal olduğu gözle kolaylıkla görürebilen suçlular hakkında ehliyetsizlik veya yarı ehliyet kararı veriliyorsa da asıl büyük kitleyi teşkil eden ve anorma! tarafı birdenbire veya birkaç duruşma devam eden hâkim - maznun münasebeti neticesinde meydana çıkamayan anormal suçlular hakkında hiçbir hususi muamete tatbik edilmiyor. Halbuki bir kimsenin suç sayilan bir hareketi işlemiş olması bile, onun biiyük bir ihtimalle, anormal bir insan olduğunu gösterir. Suç hâkime anormal bir insan karşssında bulunduğu şüphesini verdiği için ve yalniz bu baktmdan mühimdir $\left[{ }^{3}\right]$.

Bu suretle ehemmiyetini ve zaruri olduğunu işaret etmeğe çalışıtğımız (suçluyu tanıma) işinde en mühim unsur suçlunun psikolojik durumudur. Suçlu-insantn psikolojisi pek çok ve pek mütenevvi unsurlardan teşekkül eder. Fakat bu unsurların iki büyük sınıfta toplanması mümlündür. Bu iki guruba, her kriminoioji araştırmasında yer verilir. Bunlar suçlu üzerinde geniş mikyasta müessir olan ve irsiyetten ve cemiyetten gelen tesirlerdir:

\section{PSTKOLOJIK VERASET}

A - GENEI. OLARAK VERASET: Veraset mevzuunu tetkike başlamadan evvel şu noktayi işaret etmekte faide vardır. Veraset mevzuu birçok kimseler tarafından ve ekseriya pekte ilmî olmiyan şẹkillerde tet-

[2] Erem, s. 772.

[3] Ferri, s. 9. 
kik edilmiş ve bunun neticesine göre veraset unsuruna, kendisine ait olmayan birtakım vasıflar isnat edilmiştir. Sebebi meçuil görünen ruh veya beden bozukluklarının bir çoğuna sebep olarak ileri sürülmüştür. Bu sebeple veraset mevzuu üzerinde yazılan kitapları okurken çok dikkatli olmak lâżm gelir.

Veraset bugün artık inkâr edilmeyen bir hakikattir. Tesirini yalnız bir ailenin fertleri üzerinde değil, trklarda ve hattâ bütün insan nevinde gösterir. Bugünki insanın vücudunda bazı izler vardırki, eski devirlerde yaşamış insandan çok farklı olduğunu ispat eder, platysma adalesi, kuy. ruk sokumu vs. gibi $\left[^{t}\right]$. Fakat yine bu izler, bugünkü insanın, geçmişteki insandan indiğini de göstermek bakımmdan manâlıdir.

Bu suretle insan nevi, urklat ve nesilden nesile devam eden aile verasetinin mevcudiyetinden şüphe edilemez. Fakat bu mevzuu tetkik ederken uğrantlan güçlïk irsi olan hâdiselexin daima sâf bir şekilde değıl, diğger unsurlarla karışı bir halde kendini göstermeleridir. Nasıl bir madenin hakiki vasıflarını tesbit etmek için onu yabancı unsurlardan ayırmak mecburiyeti varsa verasetin esas vasıflarını tesbit için de böyle bir işe girişmek mecburiyeti vardır.

Diğer taraftan veraset hakkında tam bir fikir tekerrür eden hâdiseleri tesbit ile mümkün olacakur ki bu ekseriya çok gụ̧̈ bazanda imkânsızdır. Çünkü irsi hâdiseler daima büyükbaba - baba - oğul - torun şeklinde ve muntazam bir zincir halinde değil fasılalarla da husule gelebilmektedir. Meselâ büyük babadan dơrt, beş nesil sonna gelen bir füruğda kendini gösterebilir. Bu sebeple işi tetkik eden kimsenin ömrü bu iki şahsı tetkike kâfi gelmez.

İnsanlarda nesillerin muayyen şecerelerden kopup geldiğini, araya yabancı bir unsurun girmediğini ispat etmek çok gạ̧̧̈ür. Bazı aile suçları, tetkikatı yapan şahsa itiraf edilmedikleri için hataya sebebiyet verirler. Şunuda unutmamak lâzımdır: Insan ırkları çok karışmış bir vaziyettedir. Çünkü birleşme işlerini, meselâ hayvanlarda olduğu gibi - kontrol etmek imkânı mevcut değildir.

Bu sebeple yukarda saydığımız mahzurlar mevcut olmadığı için veraset meseleleri hayvanlar ve nebatlar üzerinde tetkik ve tecrübe edilmiş ve alınan neticeler insanlara teşmil edilmiştir ki bunada tam bir ilmî metot demek oldukça güçrür.

$\mathrm{Bu}$ tecrübeler neticesinde bulunan kanunlardan en meşhuru Mendel kanunudur. Mendel tecrübelerinden birini (Mirabilis Jalapa) denilen nebar üzerinde yaptı. Bunun çiçekleri beyaz ve kırnuzı olmak üzere iki

[4] Cooper-Cole, s. 9. 
türlüduir. Beyaz ile kırmızı çiftleştirilirse bir taksim dört nisbetinde beyaz, bir taksim dört nisbetinde kırmız, bir taksim iki nisbetinde penbe elde edilmektedir. Bu suretle elde edilmis olan kirmızlar kendi aralarında çiftleştirilirse elde edilen çiçeklerin hepsi kirmızıdır. Eğet yine bu suretle elde edilmiş beyazlar kendi aralarında birleștirilirse hepsi beyaz çiçek verir. Fakat penbeleri kendi aralanında birleştirirsek elde edilecek çiçekler bir taksin dört nisbetinde kirmız, bir taksim dört nisbetinde beyaz ve bir caksim iki nisbetinde penbedir. Tecrübeye ne kadar devam edilirse edilsin elde edilecek renkier bu nisbetler dahilinde tekerrür edecektir. Görülüiyorki bu çiçeğin vasıfları intikal etmekte ve intikal hâdiseleri muayyen nisbetli bir kanuna dayanmaktadir. Beyaz kirmızı esas renklerdir. Penbe muhtelit vasif arz eder.

Fakat bu muhtelit vasıf ancak bazı nevi nebat veya hayvanlar hakkında mevzuu bahis olmaktadır. Cünkü her nevide vasıflar aynı şiddette olmadığından ikisinin karışmasından mütevellit bị mutelit nevi (Pembe) hasıl olmaz. Bilâkis iki vastftan birisi verasete hâkim olur. Buna hâ. kim vasıf (Caractère dominant) denir $\left[{ }^{5}\right]$.

Yine Mendel sarı ve yeşil renkleri ihtiva eden diğer bir nebat ize. rinde bir tecrübe yapmı̧ ve şu netičyi elde etmiştir: Bir taksim dört nisbetinde yeşil, bir taksim dört sarı, bir taksim dört sarı, bir taksim dört sarı (mecmuu üç taksim dört nispetinde sarı). Eğer bir taksim dört sarı ile bir taksim dört diğer sarı birleştirilirse netice yine şudur: Bir taksim dört yeşil üst tarafi hep sar1.

Görülüyorki bu birleşmede muhtelit bir nevi hasıl olmuyor. Iki renkten biri (sarı) diğer renğe nazaran verasette hâkim rol oynuyor. $O$ halde bu nebatta hâkim karakter sarıdır.

Mendelin araştırmaları ve elde eqtiği neticeler yirminci astın başına kadar unutulmuş̧ư $\left[^{b}\right]$. Bu asrın başındaki vardığı neticelerin doğru-

[s] Nevillie, s. 203.

[6] Kökay (Eahnoatin Kerim) s. 54: (Avustumyjionn Buunn sehriglde nebatat ve hay-

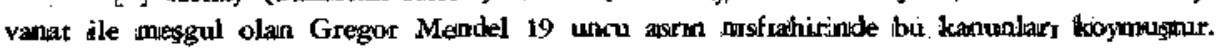




ayn ayrr değill, birtininki diğerine galebe exterek meydaña clkar. Diğeri gizli kalıx Birine

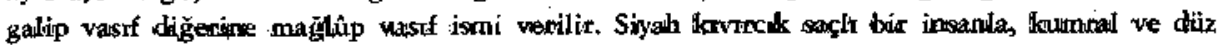

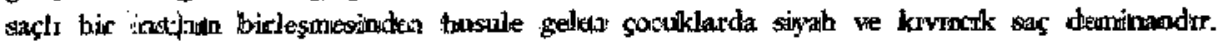

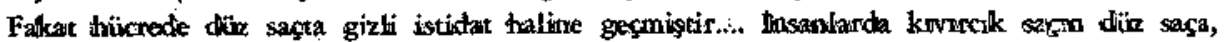

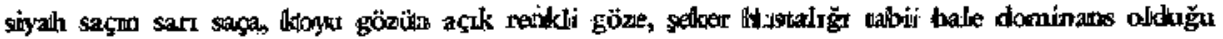

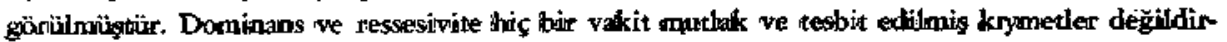
ler. Datha ziyade nisbildir. Sonsa aynt bir istidat, diğer istikckat mürvachesinde dominan olduğu 
luğu anlaşılmıs ve mendel kanunları ele alınarak tekemmül ettirilmiştir. Bilhassa Amerikada veraset meseleleri ilmî bir sekilde tetkik edilmektedir. Morgan [j] aynı birleştirme işini sineklerit bir nevi üzerinde yapmış ve aynı mahiyette veraseti ve intikal nispetletini ispat edici neticeler elde etmiş̧ir.

Veraset meselesinde intikali temin eden unsurun hücredeki kromo. zomlar olduğundan bugün artık şüphe edilmiyor. $\left.{ }^{8}\right]\left[\begin{array}{l}3 \\ ]\end{array}\right.$

Veraset meselesinde ispat edilmiş hususlar şunlardır:

1. Ana babanın vasıfları aynı ise bu vasıflar çocuklara geçer.

2. Eğer ana ve babanın vasifları arasında ayrilık varsa o zaman Mendel kanunlarını tatbik etmek lâzımdır.. Çocukların bazıları muhtelit

3. Veraset yolu ile intikal eden bazı vasıfların çocukta patiak vervasif arz edebilir.

mesi için uygun muhit ve şartlara ihtiyaç vardur. Bu son nokta adli psikoloji bakımından çok ehemmiyetlidir. Ekseriya bizi tereddüde düşürür. Suç amili olan ruh bozukluğu irsi midir $\left[{ }^{10}\right]$. Yoksła cemiyetten iktisap edilmiş bir vasıf mıdır? Bunu kesin surette halietmek çok zordur. Bu

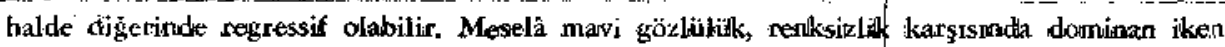

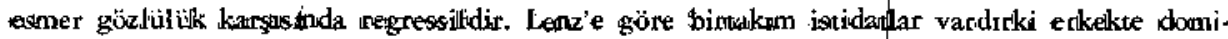
nan ikk kandsoxta regressiftuir. Sonra geoglijkte aşikâr regtessif olan muayyen istidatlar ihtiyarlikia domituan veyahuht aiksidic.)

['] Morgan'in atasturnalari hakkinda, Neville, s. 204.

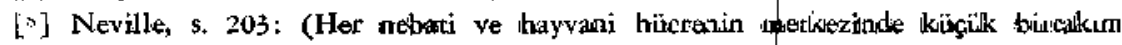







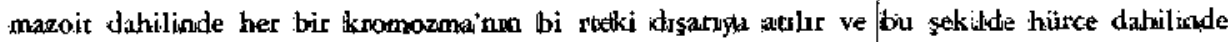

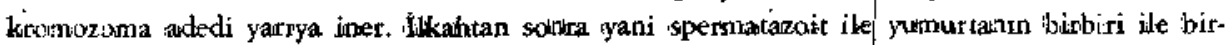

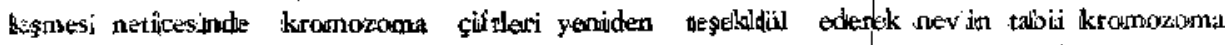

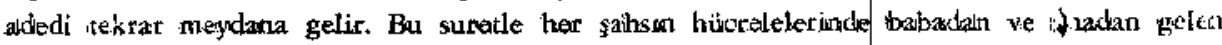
ayn adette kromozoma tesactüf edilir ve her bir kromozoma sifi biri anadas dig̈eri babadan gelen unsurlar teskil eder.)

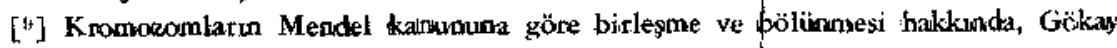
(Farettion Kerim) s. 54.

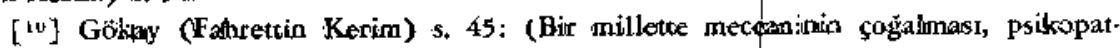

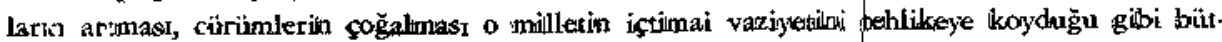

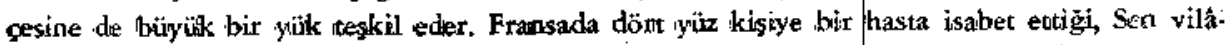
yetinde 275 kişiye diisstïğit, bu hastalarmn calnşmamataurr, beslenmłleri, mncip oldukları zamrLar Fransız bütçesirzde milyoular milyarlar teşkil ediyor. Psïkopatların, mikrimalerin, diğer

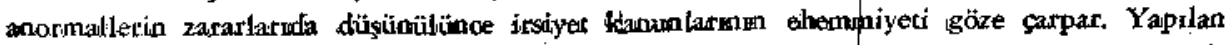

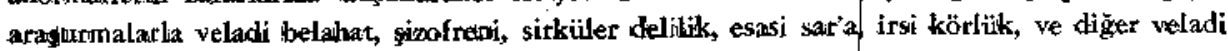

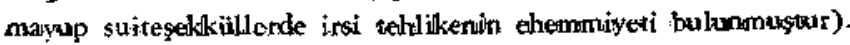


tereddüt nazari hal değildir, tatbiki ehemmiyeti büyüktür. Çünkü bu ihtimallerden biri veya diğerinin kabulüne göre alınacak tedbirler değişecektir. miştir:

Insanlar üzerindeki veraset tetkiklerinden şu neticeler elde edil-

a) Yapılış veraseti: Boy, kafa tasındaki bususiyetler (kafa tasının en geniş ve en uzun noktaları arasındaki mesafeler gibi) çene, burun, kulak şekilleri, gözlerin cildin rengi v.s. Anatomik vasıfların intikal ettiği gözle görülmekte ve herkesçe teslim edilmekte olan bir hakikattır.

b) Dahili uzuvlar veraseti: Bu veraset şekli diğerlerinden daha geç müşahade edilmiştir. Bir ailenin bütün fertlerinde kendini gösteren mide ülseri, böbrek hastalıklan, muayyen yașta gelen irsi sağırık, irsi miyopluk, renk körliiğï (daltonizm) v.s.

c) Biyolojik veraset: Bilhassa son araştırmalar neticesinde kan gutuplarının irsiyeti meydana çıkmıştı. Ana babanın gurubu aynı ise, çocu. ğun gurubuda aynıdır. Eğer ana veya babanın kan gurubunda ayrılık varsa Mendel kanunu hükmünü yürütür.

Biyolojik irsiyetin diğer bix halide medeni veya nebati zehirlere karşı bazı kimselerde görülen muafiyet halidir. Diğer taraftan hastalıkların bazılarına mukavemet veya mukavemetsizlik, bazı hastalıklardan fazla mïteessir olmak gibi hallerin de irsiyeti tesbit edilmiştir.

§) Irsi hastalıklar: Hastalıkların bazılarıntn irsi olduğu muhakkaktır $\left[{ }^{11}\right]$. Firenginin irsi olduğu zannedilmektedir. Fakat buna rağmen ana rahminde teşekkül ederken bazı fizyolojik sebepler neticesinde çocuğun bu hastalığa karşı muafiyet elde etmesi ve hastalıksız doğması mümkündür. Koku almamazlık, erken bunama, titreklik irsi hastaltklardandit. Verem için veraset şekli katî olarak ispat edilememiştir. Fakat verem. lilerin çocuklarında vereme istidat daima görünür. Kronik hale gelmiş alkolizmin veraset yolu ile intikalinc raslanmıştır.

Görüliuyorki bu dört nokta tereddütsüz kabul edilen hakikatlerdendir. Fakat acaba bunlara beşincisini ilâve edebilir miyiz? Yani nasıl, boy çene, kafatası ölçüsü ve diğer nispeten maddi diyebileceğimiz vasıfların intikali gibi baba ve ananın psikolojisi de evlâda intikal edermi? Eğer bu kabul edilirse verasetin suçlu psikolojisine teşmili mümkündür. Bunları kusaca ifade edelim:

Insan psikolojisi irsi midir? Itsi suçluluk mevcut mudur? Şimdi bu iki sorunun cevabını araştırabilitiz:

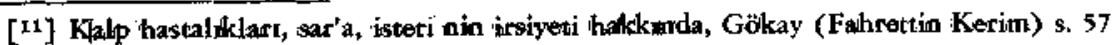




\section{B - Irsî insan psikolojisi:}

a) Tabï itişlerin intikali. Hâdise evvelâ hayvanlar üzerinde arașrırimış:ır. Tavuğun altına konan ördek yumurtasından çıkan yavru derhal suya doğru koşar, tavuk anadan bunu görüp taklit etmesine imkân yoktur. $O$ halde yeni doğmuş bir hayvanı buna sevkeden nedir? Bazı böcekler mevsim sonunda yumurtaların bırakırlar ve yumurtanın yanınada çıkacak tıttılın yiyebileceği bir gıda maddesini de bırakmayı unutmazlar. Mevsim sonunda ölürler. Yumurtadan çıkan yavru ölü ana babanın bırakı̆ğı gıda ile ilk günlerini geçirir. Ana babayı buna sevkeden nedir? Daha yıl görmemiş bir sincap kışın yaklaştığını hisseder ve bir kovuğun içinde yuvasinı ve kışın yetecek kadar gıda ambarını düzer, bu his nereden geliyor? Tatlı su balıkları bir nevi az derin sularda dogarlar büyüdükçe derin sulara hicret ederler, fakat yavrulama zamanı geldimi, doğdukları aynı mahaile avdet ederler, ve doğdukları aynı mahalle yumurtalarını bırakırlar. Ana balığa bu hissi veren nedir $\left[{ }^{12}\right]$ ?.

Bütün bu misaller gösteriyor ki hayvanları şuur ile izah edilmesi mümkün olmayan bir psikolojik unsur muayyen bazı hareketlerde bulunmağa sevk etmektedir. Buna tabii itiş diyelim. Tabii itişin insanlarda da mevcut olduğu aşikârdır. Hayvanlarda olduğu gibi, bu his bilhassa şı hususiyetleri arz eder:

aa. Tabii itiş her türlü tecrübe ve görenekten evvel, insanda doğuștan mevcuttur. Insan zekâsı ise tecrübe ve hâdiselerin tesiri ile yavaş yavaş inkişaf eder.

bb. Zekâ ve şuurun emeklemesi, yantlması, sonna hatasınt anlayarak doğru yolu tekrar bulmast zikzaklar çizmesi tabii itişte yoktur. Tabii itiş mihaniki bir emniyetle hareket eder ve dosdoğru yolunu bulur $\left[{ }^{13}\right]$. Tabii itiş tekâmül etmez, kıymetini kaybetmez, kıymetlenmez, olduğu halde kalır $\left\{^{1+}\right\}$. Uğradığı değişmeler istisna denilebilecek kadar azdır.

Bu suretle hususiyetlerini kısaca anlattığımız tabii itiş irsi midir, bundan şüphe edilemez. Bir kısmı ferdin bir kısmı nevin bekasını temin eden bu tabii itişlerin verasetten başka bir sebeple izabına imkân yoktur.

b) Hissetme hassalarının intikali.

aa. Dokunma - psikoloklar dokunma (lamise) ya umumi dil adını takmışlardır. Bu his her canlıda bulunur $\left[{ }^{15}\right]$. Dokunma deri ve adale

[12] Tabiti itişe diğer unisaller hakkunda, Thoomas, s, 191, 275.

[13] Ribot, s. 12.

$\left[{ }^{3+}\right]$ Dwalshauvers, Psilkooloji, c: Mustafa Sekip Tuns, s, 170.

[15] Ribot, s. 40. 
hassasiyetinden gelir, acı ve tath hisler uyandırır $\left[^{16}\right]$. Husule getirdiği bu psikolojik netiçeler dolayısı ile diğer hissetme hassalanı gibi bir psikoloji mevzaudur.

Dokunmanın irsiyeti kabul edilmiştir. Bazı kimselerde irsi olarak cilt üzerinde ufak bir tazyikten dayandmaz acı duymak hassası bulunur.

bb. Görme - Görme ile ruh arasındaki rabita çok büyüktür. Ani olarak kör olanlarda görülen çlldırma hâdisesi anadan doğma körlerin hafıza ve muhayyelesinin gözleri gören kimselerden daha çok başka türlü olduğunun anlaşılması bunu ispat eder.

Görme uzuvunun teşekkülü şekli, kuvveti şahıstan şahsa değiştiği gibi bilhassa aileden ailyee de degișmektedir. Itsi miyopluk, ve buna benzer hallerin intikali sık ssk görülür.

cc. Duyma - Düşünmeye dayanan fikir ve birçok ruhi hâdiseler kulaktan alınan ses intibaları ile teşekkkül ve inkişaf etmiştir. Anadan doğma sağxrların; anadan doğma dilsiz olmaları, zekâca tam inkişaf etmemeleri duyma ile psikolojik âlem aarsındaki rabıtaları gösterir $\left.{ }^{1 i}\right]$ :

Duyma kabiliyetindeki sakatlıkların irsi şekilleri tesbit edilmiştir. Bilhassa bu hal daima aynı yaşta kendini gösterit. Babanın sağır olmağa başladı̆ğ yaşta evlâdın duyma hassasının eksilmekte olduğu ispat edilmiştir. Büyük müzisyen yetiştiren ailelerin mevcudiyeti, de, duymada irsiyetin delilidit.

c) Hislerin ve ihtirasların intikali:

aa. Ifade: Bazı ruhi tembihlerin husule getirdiği reaksyonlar, tam manası ile irsidirler. Anadan doğma kör bir insan kızınca çehresinde ve diğer uzuvlarında hasıl olan reaksiyonlar gören insandakinin aynddı. Yüzün kızarması, kalb vuruşunda artış vs. Diğer ihsasların doğurduğu, gülme, yüz ekşitme, tüylerin diken diken oluşu, el titremesi gibi hallerde herkeş̧e malûmdur. $O$ halde rk farkı olmaksıżn dahi, muayyen hisler muayyen ifade hareketleri doğurmaktadır ki bunu müktesep bir kabiliyet değil, irsi bir hassa olarak kabul edebilitiz.

bb. Thtiraslar: Bunların arasında yalnzz oburluk, alkola düşkünlük, cinsi faaliyette ifrat gibi nisbeten maddi tezahürlü olanlartn değil, hasislik, bir ideal peşinde koşma, fedakârlık, kumar veya yalnız kendini düşünme gibi olanların da irsi oldukları ispat edilmiştir.

O halde şimdiye kadar söylediklerimizi nazara alarak, bu bahsin başında kendimize sorduğumuz sualin cevabını verebilixiz. Insan psikolojisi geniş mikyasta irsidir. Bu kabul edilince ikinci sualin cevabıda kısmen

[16] Chnétien, 5. 267.

[17] Bowain, s. 255. 
verilmiş oiur. Çünkü suçlu psikolojisini umumi psikoloji kanunlarından ayırmak imkânsızdır.

C - İrsi suçlu psikolojisi: Bu mesele müsbet şekilde ilk defa Amerikada tetkik edilmiştir. Amexikan araştırmalarının fyiliği ve doğruluğu seçilen metodun istünlïğünden gelir: Tecrübe ve müşahade. Bilhassa ikizler nazarı itibara alınmıştı. Aynı ana ve babadan aynı zamanda iki çocuğun, doğar doğmaz birbirlerinden ayrılması ve başka başka muhitlerde yetiştirilmesi ve elde edilen neticelerin tesbiti şeklinde yapılan bu tecrübelerden inandırıcı neticeler elde edilmiştị. Yalnız burada dikkat edilecek bir nokta vardır. Müşahade edilecek çocukların hakiki ikizler olmasıdır. Yani bir tek yumurtanın ilkahından hasıl olmalıdırlar. İstisnai abvalde husule gelen ve iki yumurtanın ayn zamanda ilkahından hasıl olan ikizlerdeki benzerlik diğerlerine nazaran daha azdır.

Bu sabada neşredilen eserlerin hemen hepsinde iki neticeye varılmaktadır. Suç ve kötü hareketlere temayül her iki ̧̧ocukta görülmüş ve fakat muhitin tesiri ile temayülü önlemek mümkün olmuştur.

Suçlu psikolojisinin irsi olduğunu tesbit maksadı ile seçilen diğer bir metotta suçluların ailelerini araştırmak, suçludan geriye doğru giderek aynı ailenin yetiştirdiği suçlu miktarı ve işledikleri suçların nevini tesbit etmektir. Bu araştırmalar neticesinde hakikaten (suçlu - aile) diyebileceğimiz ailelerin mevcudiyeti ve işlenilen suçlas arasında az çok bir benzerlik olduğu müşahade edilmiştir. Birkaç misal verelim:

Amerikada Hütson ayaletinde birkaç suç iş̧emiş ruh bozukluğu had devrede olan bir kadın kendi seviyesinde bir erkekle evlenmiştir. Bu kadından gelen seksen füruun dörtte birinin suç işlediği ve geri kalan üçte dördünün alkolik deli, yarı deli, ahmak ve dilenci oldukları görülmüştï !

Junkes adında ve 18 inci astın ilk yarısında yaşayan ve alkolik ve serseri olarak tesbit edilen bir şahsın kurduğu aile tetkik edilmiştir. Bu şahsın muhtelif kadınlardan doğan çocukları dax bit muhit içinde kalmışlar ve dağılmamışlardır. Çocukların bazılarının bizzat kendi kızkardeşleri ile münasebette bulunduklanı ve çocuk sahibi oldukları görülmüştür. Bu suretle verasetin tesiri daha bariz olacaktır. 1840 yllinda bu ailenin şeceresi araştırılmış ve bunlardan 834 kişinin mevcudiyeti tesbit edilmiştir. Bu 709 kişi içinde 106 tane serseri, 181 fahişe, 142 dilenci, 64 acizlere Devletin yaptığı yardımla geçinen kimseler olduğu 86 tanesinin suçlu ve 


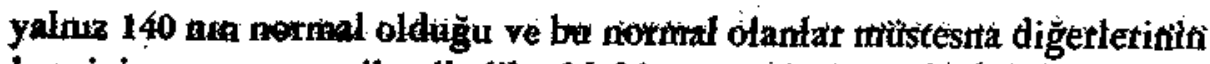



Fuhşa temayülün de irsiyeti kabul edithtektemdir. Pakat bu salhada yapılan aile tetkiklerini bir neticeye bağlamak çok müşkửldưir. Çừrikü


sorulara yanliş cevap verikler. Bu güçlikltefitie ragmetr Prof. Bonger $\left[{ }^{21}\right]$


ğini bildirnektedits: Ilki falbişe ananin dört, beş fahişe ananin ụ̧̈, on fahişe ananın iki ve 24 fahişe ananın bir kızının fahişe olduğu görülmüştür.

Şüphesiz suçla aileler üzerinde ataştirma usulä müsbet netice verebilir. Yalnız insanlar üzerindeki irsiyet araştrrmalarında hata ihtimallerìa daima gözönünde tütmalıdır. Drğer taraftan sǔçlu aile üzerinde tet-


tesbitine imkân bulunamamak gib̆̀ güçlükklex $\left[^{22}\right]$ daima mevcuttur.

Suçlu psikolojisi izerinde yapulan tetkikletîn verdiği neticeler, bìtiän sebebi veraset olarak kabule inkkân vermemektedir. Muhakkakki in thit veraset kadà ve hattât ondan daha fazla suçlü psikolojisi üzezinde mïiessirdir. But tesir bazi cemiyet yapistna bağlı sucçlularta daha fazla kovdini göstermaktedit. Fğger fahişe anadan yine böyle bix evlat dóğmaş ise, bunda her halde rerasetten ziryade muhit, görenek, sürüklentine tesirlerini aramak lâzım gelecektir. Suçlu psikolojisi kanantunnza göre, bu iki

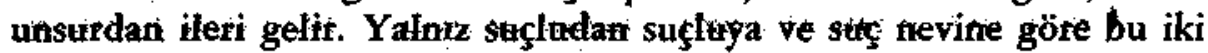
unsurdan birinin rolü diğetletine hâkin olabilitr. Hattâ diğeri mevcuł ofmasa dahi baż nevi stçlart meydana getirekìlir. Evveldèn; şekillete bağlı kalarak ve bütün suç ve suçlulara tatbik edilefilit bir käidénił bur-

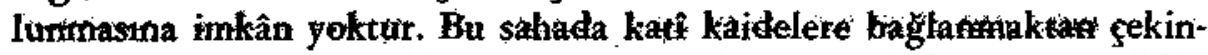
melidir. Her hâdiseyi tetkik etmeli ve ondan sonra hüküm vernekeldì.

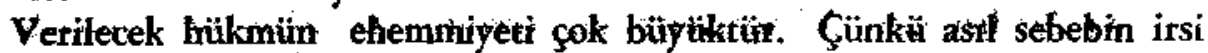
veya içtimai oluşuna göre suçlu hakkmda tatbik edilecek tedbirin nevi değişecektir.

Irsi olduğg şäphe dişinda olàn vakalarda katì tedbirlete müracaat etmeğe cemiyetin hakki vardu. Eski devirlerde babałlatinin suçundan dolayı çocukları da ceza görürlerdi. Daha medeni bił devirde yaşadıgumrz için böyle bir tredbire mitracaak edemeyiz, fakat cemiyetin bünye-

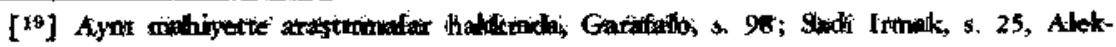

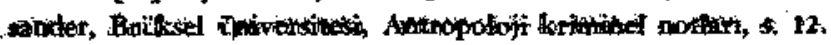



[2] A Aleksinder, o. 1 y

[22] Gutrilo; s. 95: 
sini bozan irsi kusurların intikaline uzayı gitmesine müsamaha edilemez. Garafalo $\left[{ }^{\lrcorner 3}\right]$ nun dedıg̀i gibi (suçıuarın çocukiarı, babalarının suçundan dolayı cezaıandırılamazlar. rakat bu çocukıarın doğmasna mäni olunabilir).

Ceza hukukundaki emniyet tetbirlerinin muvaffakiyeti suçlu psikolojisinin sebeplerinin iyi teşnis ve tesbitine bağłıdır. Bılhassa ceza ve. cezanın infazı meselelerinde ceza hukukuna yol göstericiliğe başlamış olan psişiyatrının verimlerinden azami derecede istirade etmeliyiz $\left[{ }^{24}\right]$.

\section{CEMIYETIN SUÇLU PSIKOLOJISINE TESIRI}

Suçiu psikolojisinin yalnız doğuştan gelen unsurlatla yapıldığını. zannetmek, içtimai tesirlere yer vermemek, veya bu tesirlerin ehemmiyetini küçükssemek doğru değildir. Cemiyet insanın doğduğu andan iti. baren hükmünü yürütmeğe başlar. İtiyatlarımızı cemiyetten kazanırız. Düşüncelerimizin, şefkat veya nefret duygularımızı büyük bir kısmı aile görgüsünden gelir. Büyüklere hürmet, aile sevgisi gibi hislerin doğuşunda aile muhitinin tesiri çok büyüktür. Diğet taraftan memleketimizin bazı taraflarında mevcut olan kan gütme halleri daha küçük yaşta iken çocuğu intikam hissi ile beslemek, büyüitmekte, nihayet kötii bir aile tesiri demektir.

Cemiyetler, insan kütleleri büyük denizlere benzerler. İçlerinde birbirine zit cereyanlar hüküm sürer. Bu sebeple suçlu psikolojisini anlamak için her halde cemiyetin büyük cereyanlarını (cemiyet kanunlarını) bilmek gerektir. lâzımdır.

Cemiyetin suçlular üzerindeki tesirini birkaç bakımdan incelemek

a) Medeniyet: Medeniyetin suç adedini azalttığını iddia etmek hemen hemen imkânsız ise de suçların nevi ve mahiyetleri üzerinde tesir icra etmiş olduğu şüphenin dışındadır. Insanlı̆̆ın emekleme devrinde (kan suçları) diyebileceğimiz suçlar şimdikinden şüphesiz daha çok fazla idi. Medeniyet bu gibi suçlar üzerinde azaltıcı bir tesir icra etmiş-

$\left[{ }^{23}\right]$ Garafalo, $\$ 276$

[24] Fahrettila Kerim Gölkay, adr geçen makaleden: (Psişiyatrinio behresi olan için de yaşadığı sosyetelerin zaafrn daha iyji görür, bumlarm sarsıntılarno menşe ve seyrini daha iyi inceler, içtimai thayatcakki bozuklukları sebeblerinji ve bu bozuklukların fertler üzerinde tesirJerini etïd ederek ona göre careler arar. Evlenome geçimsizlik, boşanma gibi aile işlerinde cemiyet barometrestain ayardnt tanzim eder. Cürümler ve diğer karanltk işistente adalet terazisj, "






tir. Bugünkü suçlar daha ziyade hileli, incelmiş zekâ eseri suçlar halindedir, buyuk dolandiriculikıar gibi.

Hakiki medenıyet suçıa mucadeleyi, başkasının hakkına el uzatmayı, önlemek işini kendıne gaye bilmıştir. Anıâk kaidelerinin insanlar izzerindeki daimi tesirinin suçu önleyıci bir tesir icra ettiği şüphenin dişındadır. Fakat muhakkak olan bir şey varsa o da cemiyetin büny și içindeki doğış̧an suçlu insanlar, vüicutta daima mevcut olan mikroplar gibi, zararsız bir halde kalırlas. Cemiyetin zayıf devirlerirde suçiarın artışı sebebi de budur.

b) Tahsil: Meşhur bir söz vardur (bir okulun açılmas!, bir ceza ceza evinin kapanmasıdır). Yalnuz bu sözün değeri, yani bir ceza eviui kapayabilmek, suçlu adedini azaltmak, her şeyden evvel okulın mahiyeưne bağlıdır. llik ögretimin suçluluğu azaltacağını zannetmiyoruz Ferri'nin dẹdiği gibi (alfabe veya gramerin suçluları azaltığını zannetmek hayal peşinde koşmaktur).

Bilgili adamın suçu daha kurnazca işlenmiş olmaktan ibarettir. Ancak bulginin yanında içtimai telkin suçu önleyici olabilir. Okulda okunan değil, görülen şey (iyi görerek) yeni teşekkül eden çocuk ruhu üzerinde sslâh edıci, iyiye yöneltici tesirler yapar. Cemiyet bünyesindeki bütiin görenekler ahenk birliği içinde, tesir yaparsa netice müspet olabilir. Bu sebeple evinde, kötü tesir altında kalan çocuğun, okulda iyi görenekle karşılaşması çocuğun (karakteri üzerinde hiçbir iz brrakmadàn kaybolup gider) $\left[{ }^{25}\right]$.

c) Iktisadi unsurlar: Sosyalistler bugünkü iktisadi yaşayıs su̧̧ kaynağı gözü ile bakarlar. İs servet bölümündeki müsavatun cemiyete aykরt düşünceleri azaltacağına, bu suretle suçu da önliyeceğine kanidirler. Sosyalistlere göre suç içtimai haksızlığa karşı bir reaksyondan ibarettir.

Inkâr edilemezki cemiyeti suçlu sayan sosyalistlerin birçok noktalarda hakları vardır. Bozuk düzensiz, tek sınıfı koruyan cemiyetler, suçlu insan zümresini mütemadiyen artırır. Yalniz her şeyi cemiyete yüklemek, suçlulart büyük bir haksızhğın kurbanları gibi telâkki etmek doğnu olamaz. Biz suç sebebinin yalṇız cemiyetten değil, suçlu insandan fertten de gelebileceğine kaniiz. Ne cemiyetin kötï tesirini ne de ferdin doğuştan suçluluğunu inkâr etmiyecek bir ceza hukukunun istikbaline kani bulunuyoruz.

Fakat şu troktaytda işaret etmek lâzımdır ki; cemiyetin muayyer: bazı sıntfları iktisadi şartlardaki ufak bir değişiklikten mühim surette

[25] Garafalo, s. 152 
müteessir olacak durumdadırlar. Günlük kazancı, günlïk ihtiyacına ancak yeten kimselerin, kazanç miktarı ile ihtiyaçlarnı giderecek miktaIn arasında daimi veya geçici bir muvazene bozukluğu mukavemet imkânına sahip olmayan kimsseleri ihtiyạ̧ için suç işliłyen kimseler vaziyetine sokabiilt. İçtimai - iktisadi krizlef, zamanında muayyen bazı suçların artı̧̧ı da bunu gösterir.

Fakat ne de olsa, içtimai unsurlarla izah edilemiyen suçlar daima mevcuttur. Hırsızlık suçunun iktisadi darlık yüzünden işlenmesi imkânı vardır. Fakat, meselâ kıskançlık yüzünden adam öldürmenin iktisadi unsurlarla, hị̧ olmazsa doğrudan doğruya, izahına imkân yoktur. İktisadi refaba fazlası ile ulaşmı̧ insanlarda bile kıskançlık, daha fazla servete malik olma hırsi veya her hangi bir kötii his suç sebebi olabilir. Eğer pozitivistlete inanmak lâzım gelirse, suçun nevine de ehemmiyet vermek doğru değildir. Işlenilen suç bir şekilden ibarettir. Adam öldürmek, dolandirıcilık, irza geçme, iftira, emniyeti suiistimal, bütün bunlar birer şekildirler, asıl mühim olan suç işleme temayülüdür. Bu temavülün haricileşmesinden, şekil kazanmasından ibaret olan suçun eheminiyeti olamaz.

Iktisadi unsurların tesiti başka cephelerden de tetkik edilebilir. Iktisadi rejimin suç üzerine tesiri ihmal edilmemeli, iktisadi düzeni kurarken suç sahasinda husụle getireceği neticeleri de gözönünde tutmahıdır. Eğer dahili ticarette serbest miibadele sistemini kabul edersek bundan birtakım suçlar dogar, birtakım suçlar azalır. Eğer fiyat murakaba ileri gidelim inhisar yahut her sahada aşır iktisadi bir Devletçilik yine bazı suçları doğurur, bazı suçları azaltır. Netice şudur: İktisadi rejimi tesbit ederken işin kriminolojik cephesini de ibmal etmemelidir.

§) Serbesti: Bazı müellifler pek haklı olarak, hürriyeti suçu artırıcı bir unsur olarak telakki ederler. Lucas, 1828 şöle yazmıştır: (Hürriyetin tekâmülünden ibaret olan medeniyet hürriyetin suiistimalini de artırmıştır) $\left.\mathfrak{[}^{20}\right]$. Çünkï vatandaşa hürriyetini kullanmak hakkı verilmezse, bu hakkın suiistimali de mevzun bahis olamaz. Bir misal alalım: Matbuat hürriyeti olmayan bir' memlekette matbuat suçlarına tesadïf edilemez. Fakat bu suç yokluğu, iyilik değil kötülük âlametidir. Diğer taraftan meselâ muayyen bir devirde, matbuat suçlarının arttığını görerek endişeye dïşmek her zaman doğcu değildir. Suç artışına mukabil, serbesti rejimindeki tahavvülleri nazara almak lâżmdtr. Genişliyen bir serbesti ile suç muvazi olarak artar. Ancak endișeyi mucip olan cihtet serbesti derecesi sabit kaldığı halde suçun artmasıdır. 
d) Kanunlar: Kanunların, bilhassa cemiyet bünyesine uymayanların, suç üzerindeki tesiri inkâr edilemez. Burada yalnız ceza kanunlart değil, bütün kanunları işaret etmek istiyoruz.

Evlenme yaşınt tesbit eden veya boşanmayı kolaylaştıran veya zorlaşuran bir kanunun gayri meşru yaşama hallerine, umumiyetle cinsi suçlarin her şekli üzerinde müessir olacağı, veya gayri meşru çocuğu tanumayı güçleştiren bir kanunun kendi veya yakınlarından birinin (namusunu kurtarmak için yeni doğmuş bir çocuğu öldürmek) veya çocuk düşürmek suçlarına geniş miyasta tesir edeceği tabiidir.

Yalnız bu sahada aşırı neticelere varmaktan kaçınmalıyız. Çünkü öyle kanunlar öyle müesseseler vardırki, cemiyet bunlardan vągeçemiyecek hale gelmiştir. Bunlar zaruridir. Meselâ gümrükler, olmasa kaçakçılık olmaz, evlenme müessesesi mevcut olmasa zina suçu husule gelmez, para mübadele vasıtası olmasa idi, kalpazanltk stiçu olmazdı. Fakat bu düşünce şüphesiz doğru değildịr. Doğru olan şey zaruri olmayan yasakların cemiyet bünyesine uymayan yapmacık müesseselerin suç üzerine tesiridir.

Münhasıran ceza kanunlarunın suç üzerine tesiríne gelince: Bunu cezanın önleyici tesiri bakımından tetkik etmek lâzımdır. Ceza mahkûmu Islâh, müstakbel suçlulart da suç işlemekten vazgeçirtecek mahiyette olmalıdır. Suç işlemeği tașarlıyan kimse, göreceği cezanın ş̧iddeti karşısında irkirmeli ve suç işlemekten sarfı nazar etmelidir. Işste bu sebeplecezaların (önleyici tesiri) olduğu kabul edilmiştir. Acaba bu düşünce doğru mudur? Psikolojik bakımdan meseleyi iki ayn cepheden araştımak lâzımdır:

aa. Normal suçlu - suçtan elde edilecek kazanç veya tatmin edilen arzu ile cezanın doğuracağı azap ve mahrumiyet arasında büyük bir fark mevcut olduğu takdirde önleyici tesir' kendisini gösterir. Böyle bir farkın mevcut olmaması hattâ bu iki vasıf arasındaki denklik suçlu üzerinde hiçbir tesir icra etmez.

Diğer taraftan unutmamalıdırki, fiilin şahısta husule getirdiği azap ve elemin çok şiddetli ve âni oluşu her türlü ceza korkusunu, tesirsiz bırakır. Açlıktan ölmek üzere bulunan kimsenin hırsızlık etmesi gibi. Kanunumuzda zanuret halinin ve buna benzer müesseselerin psikoloji bakımından izahı budur.

Normal suçlu üzerinde cezanın sadece şiddeti değil, muhakkak olşu önleyici tesir yapabilir. Her suça ölüm cezast verlimiş olsa dahi, suçların azalmasını temin etmeğe imkân yoktur. Suçlunun, suç işlediği anda, muhakkak ceza göreceği kanaatını taşıması lâzımdır. Hệ suçlu, cezaya 
katî değii, muhtemel bit netice gözï ile bakar. Suçluda en ứak bir kurtuluş umıdini bile birakmazsak ancak o zanan cezanın onteyıcı tesırıncien bahsedebiliriz.

bb. Anormal suçlu - Bunlar ïzerinde ne cezanın ısiâh edici, ne de önleyici tesiri vardır. Anormal suçlusara verilen ceza, cemiyet men. faatı bakımından, hiç fayda temin etmez.

e) Büyüik içtimai hâdiseler: 'Ietkik ettiğimiz sosyoloji unsurlar fert üzerinde topluluğun tesirini göstermeğe kâtidir. Cemiyetin fert üzerinde bazı istisnai hâdiselerin tesiri ile daha hâkim birvaziyete gȩ̣tiği, bazan onun bütün iç dưrumunu mahvettiği göruilmüştür. birbirnni takibeden ve uzayıp giden ezici hâdiseler, iktısadí güçlïkler, haroter, kara haberler, insanların asabını ve kendilerine inanma kudretini azaltrr: (Harb sahasında yanında bir obüs infilâkını takıben dili tutuianlar, eli çolak, beli kanbur, ayağı topal oiup bilâhare ruhî bir telkin ile açılanlar çoktur. Keza uzun müddet cephede mahrumiyet içersinde yaşayanlarda, talihsizlikle esir olup uzun müddet tel örgülerde kalanlarda erken bunama tablosuna müşabeheri ́evkalâde arzeden esaret psikozzlart görülmektedir) $\left.{ }^{[2 i}\right]$.

Cemiyetin tesirleri iyi olabileceği gibi, kötìde olabihir. Suçluya cemiyetin ne şekilde tesix ettiğini, cemiyetin teşkilâtlanmış olup oinamasina görede tetkik etmekte fayda vardır.

A - Şekilli topluluklar: Bunlara cemiyetler ismi vermeh̉ daha dơgru olut. Bir şekle bağlıdırlar, ekseriya hükmi şahsiyeti haiz ve evvelden tesbit edilen prensip ve kaidelere uygun şekilde hareket ederier. $A$ zalarının kimler olduğu, hakları, vazifeleri malûmđur. Ázalarından birinin yoisuz hareketi karşısında suçlunun kim oldugugnu kolaylıkỉa tâyin etmek mümkündür.

Şekilli topluluklar, teşkilât, iş bölümü, ahenk içinde çanişırna bakımından bir uzviyet gibidir. Muntazam ve makul işler, muayyen bir gayeye doğru yol alır devlet, muhtelif kurumlar, siyasi fırkalar, şirketler baro vs. Bunlar hep şekilli topluluklardır [28].

Işste bu şekilli toplulukların suçlu psikolojisi üzerindeki tesiri şekilsiz toplulukların tesirine benzemez. Tesir iyilliğe doğrudur. Şekilli cemiyetin gayesi intizamsızlığı, anarşiyi önlemek ve hâdiseleri tesadüfün seyrine brrakmamaktır. İeal şekilde teşkilâtlanmı̧̧ bir topluluk içinde suç miktarının, çok asgari hadde indirilmesinin mümkün olduğu kanaas-

[26] Garafalo, s. 184

[27] Gölkay (Fahrettin Kerim) s. 66

[28] Kesier, 5. 123 
tindeyiz. Eğer halen şekilli cemiyetler içinde de suç işleniyorsa bunun sebeoi teşkuâtın iyi olmaması veya iyi işıemeyişi veya bu teşkilâtın suç işienen muhite kadar ulaşmamasıdır

Fakat teşkilât ne kadar zayıf olursa olsun, teșkilâtli toplulukiartn suçlu insan üzerindeki tesiri, teşkilâtsız toplulukların tesirıdnen daha az bozucudur. Çünkï teşkilâtlı toplulukiar, âzalarına bazı mânevi kuvvetler verir. Fert bu kiymetleri münakaşa etmeden, bilmeyerek kabul eder. Bu kıymetler onun için en büy ük hakikatlerdir.

Ilk iptidai topluluklardaki ceza sistemi bir işkence halinde idi. Yavaş yavaş topluluk şekil kazanınca caza insanileşti. Bugünkü cezà sisteminde iş̧kence vasfı yoktur. Geçmişten kalan izlerin de yavaş yavaş silineceği ümidini veren belirtiler vardır.

$\mathrm{Bu}$ işgenceden insanileşmeye doğru giden anlayış tekâmülünü̈ cemiyetin teşkilâtlanmasına borçluyuz. Cemiyet bize diğer insanların hattẩ bunlar suçlu bile olsalar, şahsma, sırf insan olduklart için, hürmet etmek kaygusunu vermiştir. Insan hakkının taıınması, ceza mesuliyeti üzerine tesir etmiş ve suçluya merhamet etmek, mesuliyetini tahdit eden sebepleri araştırma mecburiyetini doğurmuştur.

Bugün suçun sebeplerini araştırıyoruz, bulduğumuz sebepleri izaha yelteniyoruz. Bu emek boşa gitmez. Çüıküi (izah etmek geniş ölçüde mazur görmektir. Anlamak için uğraşan her kứdret, vurmak için uğraşacak, kudreti azaltur) $\left[^{29}\right]$.

Cemiyetin kudreti karşısında ferdî unsurlar değerinị, mühim mikyasta kaybetmiştir. Cemiyetin tükenmez ömrï yanında insan hayatı saniyeden daha kısa gözükür. Bütün ağırlığı ile fert üzerindeki cemiyet baskısı, suç denilen hâdise ife az çok ilğilidir. Suçun içtimai sebeplerini araştırmak için sarfedilen gayret, yalnız suçlunun mesuliyetini azaltmakla kalmaz, cemiyetin bir ferdi olmak bakmmindan bizim mesuliyerimizi de ortaya kor. Suçsuz olan bizlerin, acaba suçlunun işlediği suçta, uzak bir mesuliyet hissemiz yok mudur? Suçluyu suçundan döndürmek için gereken tedbirleri almak elimizde iken niçin almadık?

Işte bu insanca soruların yükü altında cemiyetin suçlu üzerindeki tesiri anlaşılmış ve mesuliyet cemiyetle suçlu arasında paylaşılmıştır. Işkencenin, dayak cezasının, gözler oyularak, turnaklar sökülerek infaz edilen ölüm cezasının niçin ceza sistemlerinden çıkarıldıkları, hürriyeti bağlayıcı cezaların ana ceza haline gelişini, küçük yaşcaki suçlular hakkinda hususi bir ceza yaratmak lüzumunu, adli tevbih, tecil, meşruter tahliye, memnu hakların iadesi, maznuna mïdafaa hakkı verilmesi,

[28] Dưu (Kâzım Nami, s. 341 
anormal suçluların teşhisi için uğraşmak lüzụmunu, alkoliklerin, keyif verici maddeleri kullananların cezaya değil, tedaviye muhtaç oldukırının niçin kabul edildiğini, bir kelıme ile insana yakışır bir ceza hukukunun doğuşunu ancak bu suretle izah edebiliriz.

B - Serilsiz toplulukiar: [3"] Buniarn fert üzerindeki tesirlerini ilmi bir şekilde ilk defa tetkik eden Gustave Le Bon dur.

Bir topluluk içinde bulunduğumuz zaman, kendimizi dinleyelim, düşüncelerimizi kanaatiarımızı tetkik edelim. Yalnız olduğunız zamankinden daha başka türlü düşündügüumüzü, hareket ettiğımizi anlariz. Bu fark topluluğun fert üzerindeki tesirindsn gelir.

Topluluk içinde ferdin şuur bakımından şahsiyeti kaybolmuştur. Fikirler, hislet tek bir hedefe gevrilir. Gustave Le Bon un tabiri ile ortaya yep yeni bir (psikolojik topluluk) çskar [ $\left.^{31}\right]$. Biz bu bölümde bilhassa içinde bir heyecan havası esen topluluklardan (sokaklarda kalabalık bir kütlenin yürüyüşü, bir kaza herhangi bir hâdise sebebi ile biriken halk yığını, kederli veya sevinçli haberleri dinlemek için umumi bir meydanda toplant1, mitinkler, nümayişlar vs. gibi) babsetmek istiyoruz.

Bazı unsurlar topluluğun psikolojisini daha bariz bir hale kor. Heyecan artar. Bunların birbiri ile temasından elektriki bir muhit hastl olmuş gibidir. mümkündür:

Şekilsiz toplulukların, yığınların vasıflarını, şöylece sıralamak

a. Yığın içinde fert, şahsi murakabasını genis mikyasta kaybeder.

bb. Topluluk psikolojisinde her şey olduğundan daha fazla büyür. Heyecanlar sevgi, saygi gösterileri, korku vseaire binlerce defa büyüyen bir adeseden geçmiş gibi muazzam bir şekil alırlar.

cc. Yığın hiçbir şeyi tam anlarnaz. Her şey müphemdir. Yığın içinde fert müphem surette hisseder, fakat hareketlerinde katî ve kırıcidır. Yıgin psikolojisi met ve ezir halindedir. Durgunlaştığı yüksekliği anlar vardır. Fakat bariz vasfı hareket için bekleyiş halidir. Patlamak için ufak bir diiğmeye basılmasını bekleyen bir bumba, bir araziyi mahvetmek için bendin yıkılmasımı bekleyen sular gibi.

çç. Hâdiseler yığın içindeki ferde başka türliu gözükür. Bir çığlık, manâsız bir bağırma, ne söylediği pekte belli olmayan bir kimsenin yüksekçe bir yerde halka hitap etmesi, kütleyi yürïÿusse getirebilir. Fakat aynı hâdiseler fert yalnzz iken cereyan etse, hareket hususunda tereddüt eder.

[80] Prins, s. 121, w. 199

[3] Le Box, s. 12 
dd. Topluluk bilmeden hissetmeden kendini fiili bir şefin idaresi altuna kor. Bunlara daha ziyade (sürükleyiciler) demek lâzımdır. SürükLéyiciler, ekseriya kafa łdamı değil hareket adamudurlar [sz].

Ekseriya ileriyi görmeyen kimselerdir. Sürükleyiciler arasinda (névrosés) lẹr, yari derilere tesadüf edilir, Sürükleyicilezde kendi nefsini konuma hissi sönmüs gibidir. Süriikleyiciler ancak normal insan oldukları ve bizzat kendileri gayeye şuurlu bir sekilde inandrkları zaman hakiki şef olabilirler. Bu sebeple ihrilâl zamanlarında binlerce sürükieyici çkabilir. Hakiki şef ise ya birkaç tanedix, ya hiç çıkmaz.

ee. Yığın içinde fert her türlü telkine kapılacak bir durumdadır. Başkalarının düşünceleri, sözleri onun üzerinde derin tesirler yapar, bu tesirler başka başka neviden türlü istikametlerden gelir, ferdin ruhunda akşí sedalar husule getirir, bunlar birleşir, bir sı̆g haline gelir Şuur kontrolünü kaybetmiş olan fertte telkin edilmeğe müsait durum uyanmıştır. Yığın harekete geçer, adamlar öldürülür, mallar yağma edilir, suçlar birbirini takip eder. Bu suçlardan kimi mesul tutacağız?

Topluluğun psikolojisini bilen için hakiki mesul topluluktur. Fakat ekseriya şöyle hareket edilmektedir. Yığın harekete geçtiği zaman suçu işlemiş olanlar yine şahıslardır. Suçu iradeleri ile işlemişlerdir, tecziyeleri gerekit.

Kanaatımıza göre bu düşünce, imkânsızlıktan gelen ara bưlucu bir hal çaresidir. Maddi bir varlık olmayan topluluğun mesul edilmesine imkân yokturi. Büsbütün cezasız bırakmadansa, suçun ikana vasıta olanı cezalandıralım. Isste kanunumuzun kabul ettiği sistem de budur. Ceza kanununun 463 üçüncü maddesi müessir fiil ve adam öIdürmek suçlarını (birkaç kişi birlikte yapmı̧ olupta failin kim olduğu belli olmazsa bunlardan her bił̧isi hakkında fiil için tâyin edilmiş olan ceza üçte birden yarıya kadar indirilerek hükmolunur). Demek ki ceza verilecek fakat bu ceza tahfif edilmiş bir ceza olacaktur. Yalnzz bu maddenin tatbiki için esas şart şudur. Birkaç kişi içinden suçun kimin tarafından işlendiğinin meçhul kalmış olmass. Suçu işliyen belli değilse, ceza topluluğa katılanlatun hepsine şamildir. Fakat eğer suçu işleyen belli ise cezayı o şahıs görecek, ceza tahfif edilmiş değil, tam olacak ve topluluga katılan diğerleri cezadan kurtulacaklardrr.

Işte kanaatımıza göre doğru olmayan cihette budur. Eğer yığınlaron șuçunu işleyen daima en kötü, en fena olanlar olsa idi, bu düşünce doğru olarak kabul edilebilirdi. Fakat büyük bir ekseriyetle yığınlarn

[32] Le Bon, s. 98 
suçunu işlemeğe alet olanlar, iradesi zayıf, yığı̆ psikolojisinin tesirlerine mukavemet edemeyecek kadar ruh iktidarsızlığı, bir nevi ruhi açiz içinde topluluğun tesirine fazla kapılanlardır. Yani işiediği suçta tabiatinda onu zayif yaratmak suretiyle mesuliyeti vardir.

Asıl küitleyi harekete getiren sinsi kuvveci cezasız burakıp kütle içinde belkide en fazla acınacak bir halde diyebileceğimiz kimseyi cezalandırmak bizi tatmin etmemektedir $\left[{ }^{38}\right]$.

Doçent Dr. Faruk EREM

[ ${ }^{33}$ ] Toplukugun psikolojik tesiri bu gün bazi memleketbende razari psitkoloji saha-



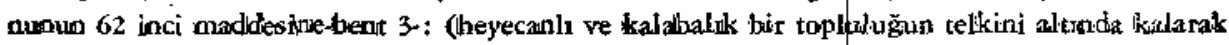

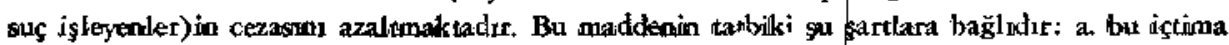
veya topluluğun hükitmer veya karwun carafrndan menelitmernis olmasi, b. failin itiyadi veyn suçu kendinde meslek edinmis koimseler - akghn kanumun m. 102, 105, 108 - den olmamasi. 